УДК $339.138+658.8$

JEL classification: M310

Писаренко Н. Л.

ORCID ID: 0000-0002-0526-8546

канд. економ. наук, дочент

Національний технічний університет Украӥни

«Київський політехнічний інститут імені Ігоря Сікорського»

\title{
СОЦАЛЬНИЙ БІЗНЕС ТА СОЦІАЛЬНА СКЛАДОВА В КОНЦЕПЦІЇ МАРКЕТИНГОВОЇ ДІЯЛЬНОСТІ
}

\section{SOCIAL BUSINESS AND THE SOCIAL COMPONENT IN A MARKETING CONCEPT}

Стрімкий розвиток соиіальних та політичних процесів в Україні за останні роки викликав бурхливий розвиток соціальної активності, як на індивідуальному, так і на інституціональному рівні, зокрема створення значної кількості соціальних підприємств. Зважаючи на прочеси полегшення створення власного бізнесу в Україні, появу нових інноваційних форм бізнесу, та зниження довіри до традииійних інститучій в Україні та світі на фоні високої довіри до громадських об'єднань та волонтерів, саме сочіальний бізнес починає відігравати все більш значущу роль в економіці. 3 іншого боку, поняття «соиіальний бізнес» та «сочіальне підприємництво» щее не визначені украӥнським законодавство. Незважаючи на це, бізнес вимушений розвиватись в рамках існуючого законодавства. В краӥні динамічно розвивається волонтерський бізнес, громадські об'єднання, кооперативи, тощо. Традииійний бізнес також залучає певні схеми та інструменти для вирішення соичіальних питань суспільства, зокрема у форматі КСО (Корпоративної сочіальної відповідальності). Зважаючи на різноманітність форм та видів діяльності, що опікується сочіальними проблемами, значно змінюеться структура ринку, щз потребує переосмислення концепції маркетингової діяльності та модифікаиії маркетингової стратегї з метою посилення соціальної складової. Наступним важливим чинником є тенденції до посилення сочіальної залученості споживачів та соціального активізму, зміни пріоритетних чинників довіри до бізнесу та брендів, в тому числі - значні очікування саме від брендів вирімення сочіальних проблем суспільства, не очікуючи дій уряду. Ці тенденції в значній мірі були підсилені в 2020 рощуі під час пандемії COVID-19 та сочіальних та економічних потрясінь, щзо ще очікуються суспільством, в тому числі і як наслідок пандемії та пов'язаних з нею урядових обмежень.Таким чином стаття присвячена поглиблення традиційної концепиії маркетингової діяльності із урахуванням соціальних тендениій. Зокрема, розглядається процес формування та реалізації соціальної ціннісної пропозиції (social value proposition) як складової прочесу позиціонування та формування конщепції бренду, формування інтегрованої моделі впровадження сочіального аспекту в маркетингову діяльність та вимірювання соціального виливу підприємства за рахунок розширення системи показників ефективності маркетингової діяльності із урахуванням соиіальної рентабельності інвестицій SROI (Social return of investment).

Ключові слова: соціальний бізнес, корпоративна соціальна відповідальність, концепція маркетингової діяльності, соціальна цінність, соціальна рентабельність бізнесу, стратегія позиціонування, соціальний активізм. 
The rapid development of social and political processes in Ukraine in recent years has caused significant development of the social activity, both at the individual and institutional level, including the creation of a substantial number of social enterprises. Given the processes of facilitating the creation of own business in Ukraine, the emergence of new innovative forms of business, and declining confidence in traditional institutions in Ukraine and the world against the background of high trust in NGOs and volunteers, social business is beginning to play an increasingly important role in the economy. On the other hand, the concepts of "social business" and "social entrepreneurship" are not yet defined by Ukrainian legislation. Despite this, the business is forced to develop within the existing legislation. Volunteer business, public associations, cooperatives are developing dynamically in the country. The traditional business also involves specific schemes and tools to address social issues of society, in particular in the format of CSR (Corporate Social Responsibility). Due to the variety of forms and types of activities that take care of social problems, the structure of the market changes significantly, which requires a rethinking of the concept of marketing activities and modification of marketing strategy to strengthen the social component. Another critical factor is the tendency to increase social involvement of consumers and social activism, changing in the priority factors of trust in business and brands, including significant expectations of the customers from brands to solve social problems of society, without waiting for government action. These trends were significantly exacerbated in 2020 during the COVID-19 pandemic and the social and economic upheavals still awaited by society, as a result of the pandemic and related government constraints. Thus, the article is devoted to expanding the traditional concept of marketing activities, taking into account social trends. In particular, the process of formation and implementation of a social value proposition as a component of the positioning process and the brand concept forming; the integrated model of social implementation in marketing activities, and the measurement of the social impact of the enterprise by expanding the system of marketing efficiency indicators taking into account social return of investment - SROI.

Keywords: social busines, corporate social responsibility, marketing concept, social value, social return of investment, positioning strategy, social activism.

Вступ. Останні роки в Україні та світі багато робіт були присвячені соціальному бізнесу, його визначенню та особливостям діяльності. Зокрема, роботи Альтер К., Емерсон Дж., Діз Г., Міллер Л., Даванс В., Долуда Л., Назарук В., Кірсанова Ю., Свинчук А.А., Корнецький А.О., Гончарова М.А., Назарук В.Я., Гусак Н.С., Туманова А.А. Проте, більшість досліджень стосувались організаційно-правовим форм організації соціального бізнесу або визначенню підходів до його класифікації або розробці методології та стандартів вимірювання соціальної активності в Свропі, зокрема, в роботах Lepourte J., Justo R., Terjesen S., Bosma N. (2013) або застосуванню концепції маркетингової діяльності в рамках соціального бізнесу - Кикол Дж., Лайонс Т. (2014). 3 іншого боку, класики маркетингової думки, зокрема Котлер, Келлер враховують соціальний аспект як важливий чинник бізнеса, проте зазначають, що багато компаній не приділяють достатньо уваги 
соціальному аспекту бізнесу на фоні підвищення вимог споживачів до нього (Kotler, 2016 с. 47).

На фоні соціальних, економічних та політичних змін за останні 5 років в Україні та світі, що демонструють дослідження Edelman (2017 2020) та Світового дослідження цінностей в Україні (Word value survey) (2020) суттєво підвищується довіра до брендів, що транслюють соціальні цінності та прагнення здійснювати соціальних вплив на фоні падіння довіри до бізнесу та державних інституцій. Все це робить необхідним переймання традиційним бізнесом певних підходів, що притаманні соціальному бізнесу, та реальне наповнення концепції маркетингу, а саме - брендів, соціальним змістом.

Постановка завдання. Метою статті $\epsilon$ 1)науково-практичне обгрунтування поглиблення соціального аспекту концепції маркетингової діяльності підприємства, 2)розширення та доповнення процесу формування ціннісної пропозиції, алгоритму реалізації ціннісної пропозиції брендів із використанням соціальної складової, 3)розширення системи оцінки ефективності маркетингової діяльності із урахуванням соціального впливу.

Методологія. Теоретичною основою проведеного дослідження стали роботи українських та європейських фахівців у сфері соціального підприємництва та соціального бізнесу. Методологічною основою виступили спеціальні та загальнонаукові методи наукового пізнання: метод теоретичного узагальнення, засоби логічного аналізу та синтезу. Інформаційною основою стали Інтернет-ресурси, результати вторинних маркетингових досліджень.

Результати дослідження. Соціально-економічні та політичні зміни останніх років призводять до суттєвої зміни поведінки споживачів, зокрема в процесі вибору товарів та брендів. Так, багаторічні дослідження компанії Edelman, що вже декілька десятиліть вимірюють рівень довіри до державних та недержавних інституцій, бізнесу та брендів - Барометр довіри (Edelman Trust Barometer та Edelman Trust Barometer. Special report in brand, 2019, 2020) демонструють зростання частки тих, хто обирає бренд, переключається 3 одного на інший, або бойкотує бренд в залежності від позиції останнього щодо важливих соціальних проблем, зросла з 51\% до 64\% у період з 2017 по 2019 роки.

Також фактор довіри до бренда посідає важливе місце серед критеріїв прийняття або неприйняття рішення стосовно купівлі (Таблиця 1), разом з цінностями та впливом компанії (бренду) на довколишнє середовище.

Дослідження у травні-червні 2020 року, що охоплювало 12 країн та 12000 респондентів показало, що під час пандемії, довіра до брендів $\epsilon$ ще більш вагомим фактором вибору. 
Таблиця 1 - Важливість факторів вибору бренда (Edelman, 2019)

\begin{tabular}{|c|c|c|}
\hline & Фактори вибору & $\begin{array}{c}\text { Відсоток споживачів, } \\
\text { що вважають цей } \\
\text { фактор важливим при } \\
\text { виборі бренду }\end{array}$ \\
\hline \multirow{5}{*}{$\begin{array}{l}\text { Атрибути } \\
\text { продукту }\end{array}$} & Якість & 85 \\
\hline & Зручність & 84 \\
\hline & Ціна & 84 \\
\hline & інгредієнти & 82 \\
\hline & $\begin{array}{l}\text { Можу довіряти тому, що бренд } \\
\text { робить правильні речі }\end{array}$ & 81 \\
\hline \multirow{6}{*}{$\begin{array}{l}\text { Атрибути бренду } \\
\text { та компанії }\end{array}$} & Доступність в каналах продажу & 79 \\
\hline & $\begin{array}{c}\text { Інтереси споживачів вищі за } \\
\text { прибуток }\end{array}$ & 78 \\
\hline & Гарні відзиви & 77 \\
\hline & Репутація & 73 \\
\hline & Цінності & 72 \\
\hline & Вплив на навколишнє середовище & 71 \\
\hline
\end{tabular}

Частка тих, хто довіряє більшості брендів, що купує зросла на $12 \%$ лише за останній рік - 3 34\% до 46\% (Edelman, 2020). 85\% респондентів очікують, що бренди будуть вирішувати їх проблеми і $80 \%$ очікують вирішення проблем суспільства. Дуже показовим $\epsilon$ відсоток людей, що вважають довіру до бренда основним фактором вибору нового бренду (53\%), що поступається лише ціні - 64\% (Таблиця 2).

Таблиця 2 - Найбільш вагомі атрибути при виборі бренду (Edelman, 2020)

\begin{tabular}{|l|c|c|}
\hline \multicolumn{1}{|c|}{$\begin{array}{c}\text { "На якому критерії вибору ви } \\
\text { фокусуєтесь у найбільшій мірі" }\end{array}$} & $\begin{array}{c}\text { При виборі нового } \\
\text { бренду }\end{array}$ & $\begin{array}{c}\text { Для того, щоб стати } \\
\text { лояльним } \\
\text { споживачем }\end{array}$ \\
\hline Ціна та доступність & 64 & 63 \\
\hline Чи я довіряю компанії або бренду & 53 & 49 \\
\hline Репутація бізнесу & 48 & 42 \\
\hline $\begin{array}{l}\text { Чи я вірю, що продукт виконає те, } \\
\text { що обіцяв }\end{array}$ & 43 & 42 \\
\hline $\begin{array}{l}\text { Наскільки добре він піклується про } \\
\text { споживачів }\end{array}$ & 41 & 39 \\
\hline $\begin{array}{l}\text { Наскільки легко його знайти та } \\
\text { купити }\end{array}$ & 38 & \\
\hline \multicolumn{1}{|l}{ Проте використання чинииів } \\
\hline
\end{tabular}

Проте використання соціальних чинників виключно як маркетинговий хід для залучення клієнтів без реальних дій відзначають $56 \%$ респондентів, але вважають, що бренди можуть зробити більше для вирішення суспільних проблем ніж держава (46\%), людям простіше змусити бренди вирішувати соціальні проблеми, ніж змусити державні інституції зробити такі дії (48\%). 
На фоні стрімкого зниження довіри до державних інституцій, в тому числі в Україні - індекс недовіри до більшості з них складає біля $70 \%$ (Центр Разумкова, 2019) ці чинники висувають вимоги принципово нового рівня задля реального впровадження соціального аспекту в маркетингову діяльність підприємств, зокрема у процеси управління брендами.

За останні п'ять років в Україні спостерігається стрімкий розвиток громадянського суспільства, виникають та розвиваються громадські організації, волонтерські руху, які часто змушені закривати соціальні та інші проблеми, що не вирішуються або вирішують в недостатній мірі державними інституціями, явно відстежується соціальний активізм (Kipnis, Pysarenko, 2016), коли саме окремі індивіди стають рушійною силою ринкових змін. Так відбувалось під час активної фаз війни на Донбасі, зокрема, допомога у відбудові армії, роботі з внутрішньо переміщеними особами, тощо. Аналогічні процеси можна спостерігати і у 2020 році під час поширення пандемії, коли громадські організації допомагають у підтримці медичної сфери. За останні роки стрімко зріс і рівень довіри до таких інституцій на відміну від державних органів влади, так в цілому громадським організаціям довіряють 46\% українців. А волонтерським організаціям - 66\% (Центр Разумкова, 2019).

Показовим є стрімке зростання соціального бізнесу в Україні як спосіб формалізації діяльності волонтерами, соціально активними громадянами, який поєднує в собі досягнення як економічних цілей (прибуток), так i соціальних (вирішення соціальних проблем). Незважаючи на те, що сьогодні законодавчо поняття соціального бізнесу в Україні ще не вирішено (як, до речі, і в деяких європейських країнах, зважаючи на різноманітність форм та методів діяльності такого бізнеса), проте існують характерні риси, що вирізняють саме таку форму діяльності. Детальний аналіз підходів до визначення наведений в роботах декількох авторів (Свинчук, 2017, Кикол, Лайонс, 2014) тому зупинимось на підході, що визначає соціальний бізнес як систематичну, в тому числі інноваційну діяльність, що спрямована на формування комбінованої (соціальної та економічної) цінності (адаптовано, Свинчук, 2017).

Характерними рисами, що вирізняє саме соціальний бізнес $є$ 1)орієнтація на створення саме соціальних цінностей, i це є більш вагомою метою бізнесу, ніж економічні цілі, 2) це має бути систематична діяльність на відміну від традиційного бізнесу, що зазвичай реалізовують короткі соціальні проекти, 3) це має біти саме бізнес, тобто побудована модель бізнесу має забезпечувати як мінімум беззбитковість діяльності, що відрізняе бізнес від громадських організацій, 4) частина або весь прибуток реінвестується у вирішення 
соціальних проблем, що чітко відрізняє цей бізнес від псевдо соціального, що просто заробляє на соціальних проблемах.

Таким чином, соціальний бізнес займає проміжну ланку між неприбутковими організаціями, зокрема громадськими, що спрямовані на вирішення соціальних проблем і при цьому не отримують прибутку i традиційним бізнесом, що орієнтований на досягнення в першу чергу економічних цілей.

Проте не можна казати, що соціальні цінності не присутні в діяльності традиційного бізнесу. Основна модель роботи в цьому випадку - Корпоративна соціальна відповідальність (КСО)ь, що за визначенням ISO здійснювати свою операційну діяльність, вважаючи суспільство та довколишнє середовище критичними факторами успіху бізнесу (ISO, 2010) i що важливо - така діяльність має бути інкорпорована в усі спекти бізнесу, в тому числі, і це є одна з ключових ланок - у маркетингову діяльність. Останні дослідження свідчать, що витрати на КСО склали в 2019411 млн грн, з яких 89\% присвячені освітнім проектам та працюють над поліпшенням умов праці та розвитком персоналу (71\%), 62,5\% займаються ініціативами в сфері екології, 91\% співпрацюють 3 громадськими організаціями та благодійними фондами (Pro Bono Club UA, 2019). При цьому у 62\% цими питаннями опікувався відділ PR і лице у 17\% відділ маркетингу. Вимірюють ефективність такої діяльності лише 25\% компаній і $52 \%$ вимірюють частково.

Таким чином можна зробити висновок, що компанії можуть активно використовувати соціальній аспект для підвищення залученості споживачів та формування лояльності до бренду не лише шляхом PR заходів або декларування соціальних цінностей, а й активного їх впровадження в маркетингову діяльність на всіх її етапах, що зображено на рисунку. Розглянемо на прикладі застосування даної схеми. Наприклад, компанія вирішує, що соціальна мета в рамках маркетингової діяльності буде доступність товарів та послуг компанії для всіх споживачів (мається на увазі споживачі 3 обмеженими можливостями) Наприклад, в 2017 році Tommy Hilfiger випустив адаптивну колекцію одягу, що легко вдягати для людей з фізичними та ментальними вадами (соціальні цінності - social value proposition (SVP) на рівні продукту; мета - бренд доступний для всіх). Одяг абсолютно підходить і здоровим людям. Він має магнітні застібки, блискавки, що можна застібнути однією рукою, тощо. Якість колекції повністю відповідає високим стандартам бренду. 


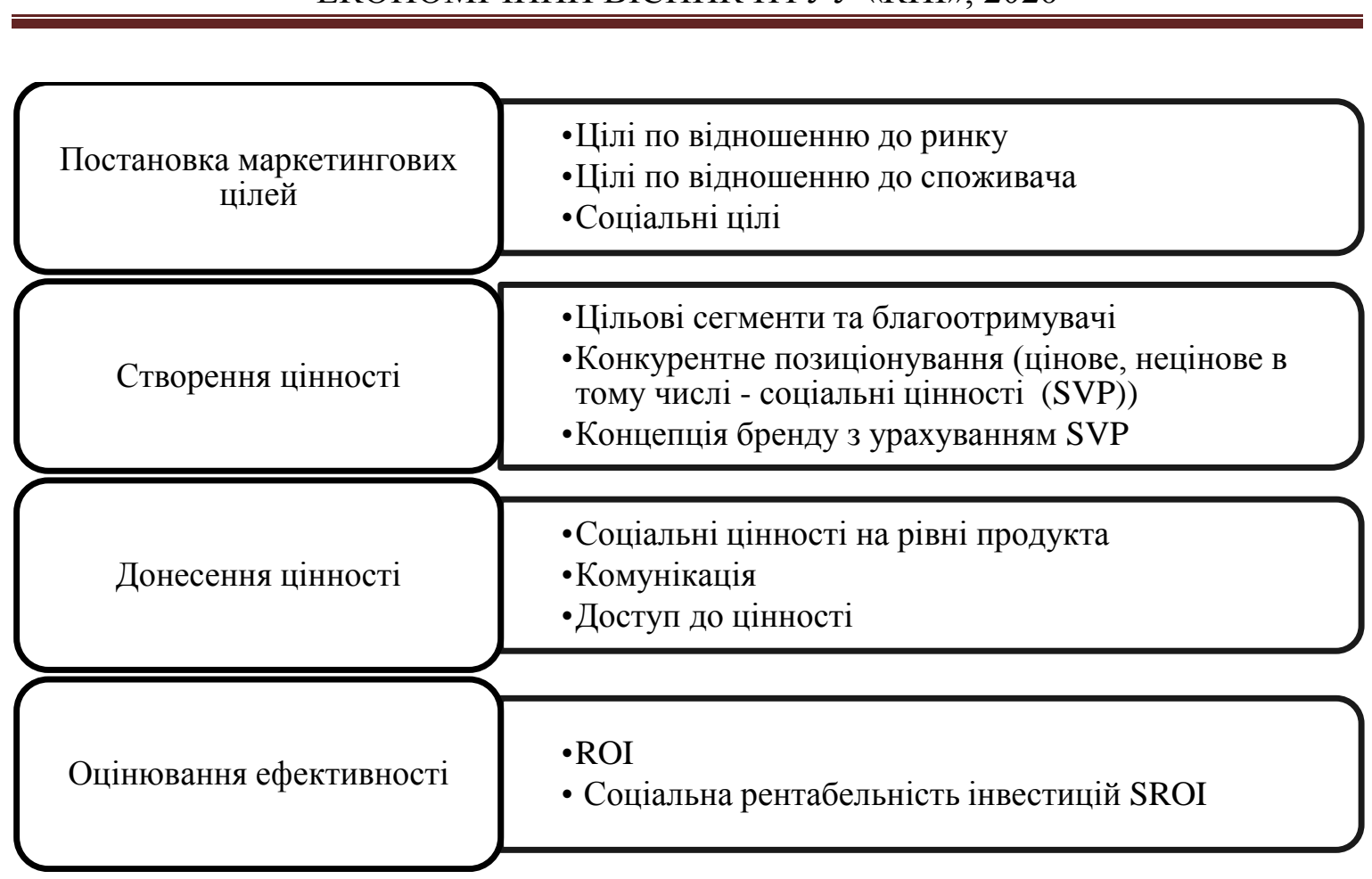

Рисунок - Схема впровадження соціальної складової в маркетингову активність підприємства (розроблено актором)

Таким чином цільовий сегмент і благоотримувач (той, на кого спрямована соціальна цінність; може бути окремою соціальною групою або суспільством в цілому) співпадають. I в 2018 році бренд запустив рекламну кампанію "Незалежність", обличчями якої стали люди 3 особливими потребами. До речі, середня оцінка кількості людей 3 особливими потребами в розвинутих країнах (Велика Британія, США) оцінюється приблизно в 20 відсотків від населення старше 5 років. Плюс родини цих людей. Тобто можна говорити, що впроваджуючи соціальні цілі (в даному випадку по відношенню до людей 3 особливими потребами) ми, в тому числі, ще й охоплюємо додатковий потенційний ринок.

Важливою складовою такої діяльності є й оцінка їі економічного і соціального ефекту. Для цього можна використовувати аналог ROI SROI (social return of investment) який демонструє наскільки велика соціальна цінність буде створена якщо досягнути поставленої мети (Social value UK, 2015, Юхименко, Писаренко, 2020). У випадку Tommy Hilfiger, SROI має враховувати не лише додатковий дохід, сформований цим сегментом, а й більш довгий в часі соціальний ефект - підвищення довіри до бренду(звичайні споживачі ), оцінювання свого життя як більш благополучного (люди з особливими потребами, опитування).

Ще одним моментом впровадження соціального аспекту в маркетингову діяльність $є$ необхідність виокремлювати соціальний бізнес як окремий тип ринку, зважаючи на домінування в них соціальних цілей та обмеження щодо прибутку. Проте співпраця 3 
такими компаніями може принести значний зиск компанії на шляху до реалізації власних соціальних цілей.

Висновки Незважаючи на відсутність законодавчого визначення соціального бізнесу в рамках українського законодавства, соціальне підприємництво стрімко розвивається та охоплює нові сфери діяльності, зокрема і за рахунок впровадження підходів, що можуть бути використані традиційним бізнесом. Споживчий вибір все більше орієнтується на показники довіри до брендів та очікування їх активної ролі у соціальних змінах в суспільстві. Такі соціальні зміни, що зараз відбуваються в Україні та світі мають бути враховані в маркетинговій діяльності підприємства, зокрема за рахунок значного підвищення соціальної складової, особливо в сфері управління брендами.

Соціальний аспект бізнесу не має обмежуватись діяльністю в рамках моделі Корпоративної соціальної відповідальності і виконувати переважно функції PR. Стратегія позиціонування та концепція бренду має бути доповнена соціальною цінністю, яка подалі має бути реалізована в ключових інструментах маркетингу, зокрема, в процесі управління товаром, комунікацією, каналами розподілу. Важливим елементом $є$ не просте декларування соціальних цілей бізнеса, а реальні кроки, що мають на меті вирішення соціальних проблем і можуть біти виміряні за рахунок соціальної віддачі на інвестиції (SROI).

Разом 3 тим, в подальшому окрему увагу слід приділити формуванню стратегії залучення та утримання клієнтів з урахуванням соціального аспекту в цифровому середовищі.

\section{Література:}

1. 2019 Edelman. Trust Barometer. Special Report. In Brands. We Trust? [Електронний ресурс] - Режим доступу до ресурсу: https://www.edelman.com/sites/g/files/aatuss 191/files/201906/2019_edelman_trust_barometer_special_report_in_brands_we_trust.pdf

2. The Edelman Trust Barometer Special Report: Brand Trust in 2020 [Електронний pecypc] - Режим доступу до ресурсу: https://www.edelman.com/research/brandtrust-2020

3. Kotler, P., Keller K. L. (2016). Marketing Management. Global edition, 15 - th ed, Pearson. - P. 833

4. Кикал Дж. Социальное предпринимательство. Миссия - сделать мир лучше. (2014)/ Кикал Дж., Лайонс Т., пер. С англ. - М.: ООО "Альпина паблишер". C.345

5. Рівень довіри до суспільних інститутів та електоральні орієнтащії громадян України (2019) [Електронний ресурс] - Режим доступу до ресурсу: https://razumkov.org.ua/napriamky/sotsiologichni-doslidzhennia/riven-doviry-dosuspilnykh-instytutiv-ta-elektoralni-oriientatsii-gromadian-ukrainy-2

6. ISO 2600. Social responsibility (2010). [Електронний ресурс] - Режим доступу до pecypcy: https://www.iso.org/iso-26000-social-responsibility.html

7. Юхименко К.І., Писаренко Н.Л, Врахування соиіального аспекту в проиесі оцінки конкурентоспроможності товару на ринку товарів та послуг для 
надзвичайних ситуацій на прикладі компанії-виробника дронів (2020)//Актуальні проблеми економіки і управління, випуск 42, Url http://ape.fmm.kpi.ua/article/view/205371

8. Lepoutre, J. Designing a global standardized methodology for measuring social entrepreneurship activity: the Global Entrepreneurship Monitor social entrepreneurship study. /Lepoutre, J., Justo, R., Terjesen, S. et al. Small Bus Econ (2013) 40: 693. [Електронний ресурс] - Режим доступу до ресурсу: https://doi.org/10.1007/s11187-011-9398-4

9. Кейт Т., Посібник з вимірювання соиіального виливу (2016)/ Кейт Т., Редут Г. [Електронний ресурс] - Режим доступу до ресурсу: https://www.undp.org/content/dam/ukraine/docs/DG/socinnov/7\%20Steps\%20to\%20 Effective\%20Impact\%20Measurement_v3_13.12.16_uk.pdf

10. Kipnis E., Consumer or Consumption Activism? Theorising the Role and Motives of Organisations in Mediating Consumer Activism in a Political Conflict Zone: Early Findings from Ukraine (2016) //Kipnis E., Pisarenko N. - Macromarketing journal: Papers for Macromarketing conference - Dublin. Ireland - 13-15 of July 2016 C 690696

11. Свинчук А.А. Соціальне підприємництво: від ідеї до суспільних змін. (2017)Посібник / Свинчук А.А., Корнецький А.О., Гончарова М.А., Назарук В.Я., Гусак Н.Є., Туманова А.А. - К: ТОВ «ПІДПРИСМСТВО «ВІ ЕН ЕЙ», 2017 $-188 \mathrm{c}$

12. Громадський активізм та ставлення до реформ: суспільна думка в Украӥні (2019). [Електронний ресурс] - Режим доступу до ресурсу: https://dif.org.ua/article/gromadskiy-aktivizm-ta-stavlennya-do-reform-suspilnadumka-v-ukraini_5

13. Social value UK. A guide to social return of investment/ Social value UK (2015) [Електронний ресурс] - Режим доступу до ресурсу: http://www.socialvalueuk.org/app/uploads/2016/03/The\%20Guide\%20to\%20Social\% 20Return\%20on\%20Investment\%202015.pdf

14. Pro bono club Ukraine. Бізнес витратив на сочіальні проекти 411 млн грн дослідження українського ринку КСB (2019) [Електронний ресурс] - Режим доступу до ресурсу: https://nachasi.com/2019/09/27/business-ksv-social-project/

\section{References:}

1. 2019 Edelman. Trust Barometer. Special Report. In Brands. We Trust? Available at: https://www.edelman.com/sites/g/files/aatuss191/files/2019-

06/2019_edelman_trust_barometer_special_report_in_brands_we_trust.pdf

2. The Edelman Trust Barometer Special Report: Brand Trust in 2020 Available at: https://www.edelman.com/research/brand-trust-2020

3. Kotler, P., Keller K. L. (2016). Marketing Management. Global edition, 15 - th ed, Pearson. - P. 833

4. Kickul, J. Social entrepreneurship. Mission in an even changing world (2014)/ Kickul, J., Lyons T.,-- M.: "Alpina pablisher". -P. 345

5. Riven doviry do instytutiv ta electorala orientatsiya hromadian Ukrainy [Level of trust in institutions and electoral trust of Ukrainian citizens]. (2019) Available at: https://razumkov.org.ua/napriamky/sotsiologichni-doslidzhennia/riven-doviry-dosuspilnykh-instytutiv-ta-elektoralni-oriientatsii-gromadian-ukrainy-2

6. ISO 2600. Social responsibility (2010). Available at: https://www.iso.org/iso-26000social-responsibility.html 
7. Yukhymenko K., Pysarenko N. Vrakhuvannia sotsialnogo aspectu v protsesi otsinky кonkurentospromozhnosti tovaru na rynku tovariv ta posluh dlya nadzvychaynykh sytuatsiy na prykladi kompaniyi-vyrobnyka droniv [Consideration of the social aspect in the process of assessing the competitiveness of goods in the market of goods and services for emergencies for drone production enterprise ] (2020)//Actual problems of economics and management, vol 42, Url - http://ape.fmm.kpi.ua/article/view/205371

8. Lepoutre, J. Designing a global standardized methodology for measuring social entrepreneurship activity: the Global Entrepreneurship Monitor social entrepreneurship study. /Lepoutre, J., Justo, R., Terjesen, S. et al. Small Bus Econ (2013) 40: 693. Available at: https://doi.org/10.1007/s11187-011-9398-4

9. Keyt T., Posibnyk z vymiruvannia sotsialnogo vplyvu. [A guide to measuring social impact] (2016)/ Keyt T., Redut H. Available at: https://www.undp.org/content/dam/ukraine/docs/DG/socinnov/7\%20Steps \%20to\%20 Effective\%20Impact\%20Measurement_v3_13.12.16_uk.pdf

10. Kipnis E., Consumer or Consumption Activism? Theorising the Role and Motives of Organisations in Mediating Consumer Activism in a Political Conflict Zone: Early Findings from Ukraine (2016) //Kipnis E., Pisarenko N. - Macromarketing journal: Papers for Macromarketing conference - Dublin. Ireland - 13-15 of July 2016 C 690696

11. Svynchuk A. Sotsialne pidpryemnytstvo: vid idei do suspilnych zmin. [Social entrepreneurship: from idea to social change](2017) / Svynchuk A., Kornetsky A., Honcharova M. - K: «Pidpryemstvo «VNA», 2017 - $188 \mathrm{c}$

12. Gromadsky activism ta stavlennia do reform: suspilna dymka v Ukraini. [Public activism and attitude to reforms. public opinion in Ukraine] (2019). Available at: https://dif.org.ua/article/gromadskiy-aktivizm-ta-stavlennya-do-reform-suspilnadumka-v-ukraini_5

13. A guide to social return of investment/ Social value UK (2015) Available at: http://www.socialvalueuk.org/app/uploads/2016/03/The\%20Guide\%20to\%20Social\% 20Return\%20on\%20Investment\%202015.pdf

14. Pro bono club Ukraine. Biznes Vytratyv Na Sotsialni Proekty 411 Mln Hrn Doslidzhennia Ukrainskoho Rynku KSV [The business spent UAH 411 million on social projects - a study of the Ukrainian CSR market](2019) Available at: https://nachasi.com/2019/09/27/business-ksv-social-project/ 